\title{
Research on Promotion Strategy of Cultural and Creative Products of Xi' an Tourism Based on Regional Culture*
}

\author{
Ran Li \\ Xi'an University \\ Xi'an, China 710065
}

\author{
Ying Liang \\ Xi'an University \\ Xi'an, China 710065
}

\begin{abstract}
Culture is a symbol of a region, and the distinctive characteristic culture of a city is the basis for developing the tourism. The featured products of tourism pay attention to innovation. Tourist cultural and creative products should be rich in the city's unique humanistic temperament, so that people can see the unique regional characteristics from its cultural derivatives at a glance. Xi'an City is a famous tourist city. In the design of tourist cultural and creative products, local culture should be fully displayed and the characteristics of regional culture should be rationally utilized. This paper makes a deep understanding and reflection on the current situation of tourist cultural and creative products in Xi'an City, analyses and studies the existing problems in its marketing, and puts forward reasonable suggestions based on the results of the study.
\end{abstract}

Keywords—Xi'an regional culture; tourism literary creation; product promotion

\section{INTRODUCTION}

Cities are the epitome of human economic, social and cultural development. A city with deep foundation and coordinated development of economy and humanities is a city with lasting competitiveness. Xi'an, the ancient capital, has long history and profound cultural connotations. With the establishment of the National Central City in 2018, the development of characteristic tourism is more promising. Against this background, tourist cultural and creative products based on regional culture and traditional skills are developing rapidly.

As a part of cultural and creative industries, tourist cultural and creative products have both the attributes of tourist souvenirs and the characteristics of cultural and creative products. It integrates knowledge and technology, takes creativity as the soul, and the connotation as the core, and creates new value in tourism industry in the form of materialization. Because of its unique connotation, tourist cultural and creative products show the profound history and culture accumulated in the city from ancient times, and become souvenirs that can be taken away and easy to collect. Souvenirs with both cultural connotations and creative forms condense the long historical charm into their own poetic and

*Found: It is supported by the thirteenth Five-Year Plan of education science in Shaanxi province in 2018 (SGH18H288). picturesque flavor, bringing visitors a deep cultural touch, which is the value of tourist souvenirs.

Xi'an City is the political, economic and cultural center of many dynasties in Chinese history, and the starting point of the Silk Road. It has made unique contribution to the survival, reproduction and progress of human history and civilization of the Chinese descendants. It is one of the sources of excellent Chinese culture. It shoulders the responsibility of actively disseminating Shaanxi regional culture, which has shown the humanistic spirit of Chinese culture. And its regional environment makes it form unique and connotative cultural characteristics.

This study will have a valuable reference for the marketing of cultural and creative products of Xi'an tourism, and have an important significance for the beautification of Xi'an city image and the coordinated development of culture and tourism industry.

\section{Present Situation OF Tourist Cultural AND Creative Products in XI'AN City}

In recent years, with the development of tourism industry in Xi'an City, it took only four or five years to complete the development process and level of other places that needed ten years. Throughout the market of tourist cultural and creative products in Xi'an City, there are two characteristics as follows: There are abundant categories of tourist cultural and creative products. They are mainly traditional folk and handicraft souvenirs, tourist souvenirs developed on the basis of famous tourist attractions in Xi'an City and innovative art derivatives. The business addresses are attached to the business circles, scenic spots, museums, bookstores and other places with dense passenger flow. Because these places can not only attract potential customers imperceptibly, but also create a situational consumer experience for consumers, so as to stimulate consumers' desire to buy and achieve the purpose of sales. Conditions for market promotion are favorable. There are many favorable conditions for the promotion of Xi'an tourist cultural and creative products. Firstly, the long history and profound cultural heritage of Xi'an City attract numerous tourists to stop and linger. Therefore, there are many consumers paying for the design and development of tourist cultural and 


\section{The Marketing Concept is Not Deep Enough}

As a business guiding ideology of "focusing on consumers' needs and starting from the market", marketing concept covers the scope from product development and design to packaging, shop environment and shopping experience. However, the current situation mentioned above that some of the cultural and creative souvenirs seldom convince customers to buy and the problems still existing in some tourist cultural and creative souvenirs reflect that the marketing concept of the developers is not deep enough.

Therefore, the better development of tourist cultural and creative souvenirs in Xi'an City requires developers to take the market as the guide, and improve product development design and product packaging, store environment, shopping experience, etc.

\section{Marketing Promotion Strategy of XI'AN TOURIST CULTURAL AND CREATIVE SOUVENIRS}

Through digging out the marketing problems of Xi'an tourist cultural and creative souvenirs, Nanjing tourist cultural and creative souvenirs show a good development trend, but there are still some shortcomings in marketing. By finding out the crux and formulating corresponding countermeasures, it can not only make Xi'an tourist cultural and creative souvenirs get better development, but also promote the coordinated development of Xi'an tourism industry and cultural and creative industry.

\section{A. Satisfying Consumers' Purchasing Motivation and Emotional Needs}

Tourists' purchase of tourism products is a kind of perceptual consumption behavior. After experiencing the cultural implications of Chang'an, they make souvenirs a precious souvenir to Xi'an based on practical, gift, novelty and cultural motives. Therefore, the demand of customers determines which kind of products in the market will flourish and which kind of products will eventually be eliminated. Xi'an's tourist cultural and creative souvenirs need to meet the emotional needs of consumers, reasonably display the cultural connotations of tourist products. And then, the customers can perceive the cultural connotations of Xi'an through souvenirs and feel the unique temperament of Xi'an. This aesthetic feeling with cultural feelings can make tourists deeply touched by culture, thus generating emotional resonance. Grasping the emotional needs of customers is also conducive to the marketing of products.

\section{B. Highlighting the Brand Influence of Tourist Cultural and Creative Souvenirs}

On the basis of identifying the core competitiveness of Xi'an culture, the market-oriented development of tourist cultural and creative souvenirs in Xi'an City needs to adhere to the brand strategy, which is the best way for customers to recognize and generate trust. For example, Shaanxi Historic Museum is the most representative of cultural collections and ancient cultural relics at this stage. When developing cultural and creative souvenirs, it should consider the value of collections and practical orientation of souvenirs 
become the motive of mass tourism and travel, and the demand for tourism is increasing. China has a long history, and the folkways and customs of various places are more colorful. The cultural relics and monuments of various places also have profound historical details. On the basis of integrating regional culture, tourist destinations provide people with various platforms for in-depth exchanges and mutual understanding, making tourism more diversified. The historical relics of tourist sites, fascinating humanistic buildings, incredible folk customs and other cultural resources have been transformed into important tourism resources with the development of China's cultural industry. Tourism culture has lasting vitality.

The integration of tourism industry and cultural industry is closely related to the promotion of economic development. Nowadays, Xi'an tourist cultural and creative products are in the primary stage of rapid development. With the rapid development of Xi'an's economy and culture, "how to seize the opportunity of tourist cultural and creative development in such a competitive environment, find the target for the sustainable development of tourism in Shaanxi Province and even the whole country, inject fresh vitality and motivation, take regional cultural elements as the center, and enhance the innovative design competitiveness of the brand of tourist cultural and creative products with Xi'an characteristics" have become an important strategic issues in cultural development.

\section{REFERENCES}

[1] Xu Weimin. Regional Culture and Characteristics of Shaanxi Province [J]. Journal of Yangtze University, 2016(05): 25-28. (in Chinese)

[2] Li Ming. Research on the integration and development of Xi'an cultural industry and tourism industry [D]. Northwest Normal University, 2015. (in Chinese)

[3] Baiyun. The Development Path of Cultural Tourist Creative Industry in Xi'an City [J]. Global Market Information Guide, 2017(08): 68-72. (in Chinese)

[4] Wang Dongdong. Pursuing the Footprint of cultural and creative industry - A Survey of Nanjing cultural and creative products [J]. Beauty \& Times (Vol. 1), 2017,( 07): 31-33. (in Chinese)

[5] Zhao Yueli, Liu Zunyue. The Research Strategy of Cultural and Creative Products Based on Museum Culture - Taking Nanjing Museum as an Example [J]. Art Evaluation, 2017(05): 167 -169. (in Chinese)

[6] Bo Wenwen. Research on Marketing promotion Strategy of Nanjing Tourist cultural and creative Souvenir [J]. Industry and Technology Tribune, 2018(17)20: 22-23. (in Chinese)

[7] Wu Tie. Discussion on Regional Culture and Xi'an Tourist Cultural and Creative Product Development Path [J]. Art Science and Technology, 2018(06): 8-9. (in Chinese) environment and services of stores are the key to experiential marketing. By grasping this point, tourists from other places can feel the humanistic accomplishment in the influence of Xi'an culture. While marketing and promotion are successful, they can also beautify the impression of Xi'an in the minds of tourists.

\section{CONCLUSION}

China has accumulated excellent traditional culture, spiritual culture and material resources. Nowadays, it has 